1) O sujeito cartesiano está vinculado à subjetividade, tema inaugurado por Descartes: eu penso, logo existo. Sou, portanto, ativo e o sujeito é o prinápio, aquele sobre o qual se funda $o$ conjunto do conhecimento, da moral, do direito. Trata-se de um ser livre e responsável. Diferente, senão oposta, é a posição de Marx, Nietzsche e Freud, para quemo sujeito é efeito de fenômenos que Ihe escapam, de relações sociais, processos inconscientes ou vontade de potência. Para o estruturalismo, o sujeito é apenas o efeito do sistema (por exemplo, da linguagem).

2) Éa posição, por exemplo, de Jean Piaget. Para ele, a inteligência não é uma forma fixa pertencente ao sujeito; tampouco é constituída de impressões que um mundo externo causaria sobre um sujeito passivo: ela é produto da gênese refletindo a interação do sujeito com seu meio, se relacionando em diferentes estádios e períodos, auja integração sucessiva é possível pelas condições biológicas do desenvolvimento. Cf. S. Auroux e Y. Weil. Dicionário de autores e temas da filosofia. Paris, 1991, pp. 377. 3) "O narrador não pretende manifestar sua competência em contar a história, mas apenas o fato de dela ter sido o ouvinte. $O$ narratário atual, ouvindo-o, elevase potencialmente à mesma autoridade./.../Os 'postos' narrativos são de tal modo distribuídos, que o direito de ocupar um deles, 0 de remetente, fundamenta-se sobre o duplo fato de ter ocupado o outro, o de destinatário, e de ter sido, pelo nome que se tem, já contado por um relato, quer dizer, colocado em posição de referente diegético de outras ocorrências narrativas". Jean-François Lyotard, O pós-moderno, Rio de Janeiro, José Olympio, 1986, p. 39.

Ciro Marcondes Filho é Jornalista e Sociólogo, Professor Titular junto ao Departamento de Jornalismo e Editoração da ECA/USP.

Ciro Marcondes Filho

\title{
Alice do país do videodrome: de como os receptores foram tragados pela interatividade da comunicação eletrônica
}

1

O tema principal dos debates sobre recepção das mensagens da comunicação centra-se numa questão clássica da cultura: será que o receptor recontextualiza o que recebe (ou seja, haveria uma certa debilidade do lado do emissor?) ou o sistema anula o indivíduo e qualquer aspiração sua à autonomia (isto é, haveria uma certa debilidade do receptor)?

$\mathrm{O}$ assunto remete necessariamente à questão do sujeito, amplamente discutida na filosofia ou, mais exatamente, na contenda entre idealismo e criticismo (ou estruturalismo) ${ }^{1}$, se bem que o debate comporte um tertius ${ }^{2}$.

E o tema desperta ainda mais interesse quando os meios de comunicação deixam sua dimensão doméstica, discreta, de veículos ou aparelhos "como todos os demais", para se tomarem sistemas complexos gerais, que enredam em sua lógica e em sua presença, em todas as direções, tudo o que é humanamente apreensível e imaginável.

Os meios de comunicação tornaramse a teia, o sangue circulante, a matéria estruturante das relações sociais, em suma, um pouco a "alma" deste século. Os alemães denominam Zeitgeist ao espírito de uma época, mas eles se referem mais a um certo comportamento, uma atitude típica que ocorreu especialmente em tempos passados. Talvez os media de massa subvertam um pouco esse conceito, deslocando-o para um sistema que se toma típico de uma época por recompor as atitudes, comportamentos, visões de mundo. O espírito de nossa época é a comunicação e o espírito do século 21 será, efetivamente, o das virtualidades, das ações à distância, da telepresença, da grande massa dos conectados, um exército social de reserva que cada vez mais se vê apenas pela mediação esterilizante, higiênica, distanciada das telas.

\section{2}

$\mathrm{Na}$ tradição oral, o ouvinte receptor, no nosso caso - é aquele que seria o próximo narrador. Ouvir, receber a mensagem, significava memorizá-la para poder reproduzi-la e garantir, assim, a continuidade do mito original e, portanto, da própria sociedade ${ }^{3}$. Opera-se uma tripla competência: a do saber-dizer, o do saber-ouvir e o do saber-fazer. ${ }^{4}$

Walter Benjamin trabalha também com a questão da narrativa - para ele "uma forma artesanal de comunicação" - e a relação do ouvinte com aquilo que lhe é relatado oralmente. Para ele, a possibilidade de encontrar alguém verdadeiramente capaz de historiar algum evento vai se tomando cada vez mais rara: "é como se nos tivessem tirado um poder que parecia inato, a mais segura de todas as coisas seguras, a capacidade de trocarmos pela palavra experiências vividas". ${ }^{5}$

Mais além, diz que a capacidade de ouvir atentamente também está prejudicada, assim como estaria se perdendo a própria comunidade de ouvintes. Benjamin baseia esta última constatação no "ouvir atento", ao dizer que "ninguém mais fia ou tece enquanto 
escuta as narrativas"'6.

$\mathrm{Na}$ reflexão de Benjamin encontramos vários elementos da crise $d a$ recepção produtiva, digamos assim, aquela forma de receber a comunicação que potencializaria o ouvinte a se tomar um novo relator. Em primeiro lugar, as pessoas já não conseguem reproduzir plenamente o que vivenciaram, perdem a capacidade de verbalizar experiências; em segundo, por força do volume de informações que a imprensa passou a veicular e também das explicações a elas associadas, já não se consegue narrar, pois narrar, para ele, não supõe ilustrar com explicações; em terceiro, ninguém mais ouve atentamente.

A criação dos tipos móveis de Guttenberg, como também assinala o pensador, teria desencadeado esse processo na medida em que o romance, que depende inteiramente do livro, teria alterado a relação física do narrador com seu ouvinte. Mais tarde, a imprensa e a política de difusão de informações teriam dado mais um golpe na capacidade de transmitir, o que teria feito homens voltar das guerras emudecidos. Na medida que um sistema assume a prática do relato, os homens se desabituam dessa atividade e neles se atrofia a capacidade narrativa. De um lado, uma máquina a fabricar histórias e a enchê-las de detalhes e informações; de outro, uma sociedade barulhenta que inviabiliza a recepção que cala no ouvinte. Efetivamente, começa a se criar no fim do século XIX uma nova cultura, uma cultura de delegação da transmissão cultural aos meios técnicos. Se por um lado ganhou-se pela universalização, pela democratização, pela popularização da informação cultural, por outro, perdeuse qualitativamente pelo atrofiamento da capacidade de ouvir e relatar, com todas as suas conseqüências para as gerações seguintes.

Isso, em verdade, não deixa de ser uma regra das sociedades tecnológicas: uma contínua troca qualitativa de um valor por outro, induzida pela inovação técnica. Onde o valor era o trabalho único, personalizado, instaura-se o produto democratizado, multiplicado; onde se estimulava o homem, o tempo extensivo, a acuidade e o esmero, agora se estimula o social, o tempo intensivo (a versatilidade, a agilidade), a rapidez e a multiplicidade. Num modelo vale o bem feito; no outro, o acessível. Onde se instalava o homem como receptor, agora está a massa. Trata-se de uma comutação cultural com novos valores, advinda da mudança tecnológica.

\section{3}

O trabalho da imprensa políticoliterária da segunda metade do século XIX foi o de realizar com o público receptor uma operação de estimulação para o ingresso na cena política através do voto e de cooptação eleitoral com políticos, grupos e partidos. Inicia-se uma nova era, a da produção de opinião pública, trabalho esse que busca seduzir o público leitor para um novo tipo de relacionamento com a comunicação; é neste quadro que começam a se colocar as questões do início: quem é que se debilita no processo, o receptor ou o sistema?

As lutas sociais do período compreendido entre as revoluções liberais e a Primeira Guerra Mundial levaram à clivagem política da imprensa no campo da politização dos meios de comunicação ${ }^{7}$. De um lado impõem-se os grandes jornais de massa, que introduzem 120 anos atrás as manchetes, os destaques, as reportagens, trabalham melhor as capas, criam as chamadas de $1^{\text {a }}$ página. $O$ interesse desses veículos são os grandes lucros que podem bancar as altas tiragens. A venda de espaço publicitário e a venda do público leitor como sua segunda mercadoria estimula altos investimentos, que passam a tratar o receptor como alguém que deve ser seduzido, deve sofrer a sugestão, se submeta às estratégias de captura e convencimento ao consumo. De outro lado, uma imprensa político-partidária sobrevive
4) Idem, ibidem.

5) Walter Benjamin. "O Narrador". In: Benjamin, W., Horkheimer, M., Adomo, T.W., Habermas, J. Textos escolhidos. Col. Grandes

Pensadores. S. Paulo, Ed. Abril, 1975, p. 63.

6) Idem, p. 68.

7) As décadas iniciais de 1800 já haviam sofrido as primeiras conseqüências sociais das

revoluções burguesas. A sociedade se transformava: nacionalismo, socialismo e liberalismo disputavam-se como opções políticas das massas. As lutas sociais ganhavam as ruas, a reforma eleitoral estendia o direito de voto a todos os homens adultos.

Os grandes partidos políticos, indusive os operários,

reivindicavam igualmente o poder da imprensa e meios de

comunicação mais efetivos para a conquista de adeptos. Surge daí, em meados do século 19, um espaço chamado « esfera pública proletária », inicialmente na

Inglaterra, com o movimento cartista. Depois, na França, com a revolução de 1848, contra a aristocracia de volta ao poder, ele marca o avanço das campanhas nacionalistas e socialistas. No mesmo ano, a liberdade de imprensa será uma reivindicação presente também na Alemanha em sua revolução de 48. Mas é nos anos que se seguem que se delineia « a grande c livagem » na imprensa: enquanto a imprensa popular ganhava as ruas, estimulando as campanhas operánias, as lutas socialistas, as conquistas sociais, os donos das empresas jomalísticas já estavam dando seu pulo do gato. A atividade que se iniciara com as discussões político-literárias aquecidas, emocionais, relativamente anárquicas, começava agora a se constituir como grande empresa capitalista. Cf. Marcondes Filho, C.,

A saga dos cães perdidos. São Paulo, Hacker, 2000, cap.1. 
8) O sucesso de um Encouraçado Potemkin estimulou a produção socialista de bens comunicacionais. O próprio Goebbels impressionavase com a capacidade fortemente magnetizante do filme e andava à procura de um produto igual para os fascistas (tentando cooptar Fritz Lang). Mas, mesmo entre os socialistas, era difíil repetiro sucesso. As tentativas do partido social-democrata e dos comunistas alemães eram geralmente débeis em comparação aos grandes sucessos cinematográficos do expressionismo. Por isso o grande êxito editorial de uma obra como História e consciência de classe, auja finalidade era abrir o horizonte dos comunistas sobre a necessidade de se pensara questão cultural nas esquerdas. Foi isso também que levou um pensador como Antonio Gramsai a ser, muitas décadas após sua morte, ainda enaltecido no campo das esquerdas: por força da limitação das obras de Marx ao plano econômico e parcialmente político, era difíil trabalhara questão da cultura no quadro do marxismo. Sobre a época, ver: Marcondes Filho, C. O discurso sufocado. São Paulo, Loyola, 1982. 9) Em tomo desta revista, no pósguerra italiano, condensava-se a questão fundamental da politização da cultura, de inspiração gramsciana: até que ponto os progressistas na política também o eram na cultura? Assim como Bogdanov submergiu ao leninismo, Elio Vittorini não reuniu forças para fazer frente ao stalinismo de um Togliatti. Ver para isso: Marcondes Filho, C. (Org.) A linguagem da sedução. São Paulo, Perspectiva, 1986, pp. 147-161.

10) Cf. análise em Marcondes Filho, C., 1982, op. cit. 11) No sentido clássico: ideologia burguesa, ideologia proletária, etc. junto aos movimentos sociais.

Do ponto de vista da relação com o receptor, as duas formas de jornalismo representavam duas visões de mundo relativas à comunicação, que naquela época só conhecia os meios impressos, ambas descobrindo o novo meio - um meio de massas - com forte potencial de mobilização e sedução. A invenção do rádio no final da Primeira Guerra e os filmes de Eisenstein, logo após a Revolução Russa, ampliariam o campo de influência e de penetração dos meios de massas, especialmente como formas de contrapropaganda à comunicação de banalidades, de produtos puramente ligados à distração, à alienação, ao erotismo.

O campo "burguês" não teorizava; simplesmente punha no mercado obras do chamado "gosto popular", enquanto o campo das esquerdas deparava-se com o enigma de um produto que fosse ao mesmo tempo bem sucedido do ponto de vista do público e que estimulasse a formação de "consciência crítica"8.

A discussão sobre o uso político da comunicação transcende à guerra, recupera-se no pós-guerra (com o neorealismo, a revista $\mathrm{Il}$ Politécnico ${ }^{9}$ ), e chega até os movimentos dos anos 60. Mas aqui o questionamento referese à própria política cultural das esquerdas, que jamais havia tratado de forma compreensiva a questão da recepção.

A chamada esquerda extraparlamentar européia dos anos 60 realiza, então, o questionamento de toda a política comunicacional anterior, que vinha desde a grande clivagem na imprensa, apontada acima: trata-se de ativar o lado do receptor, levá-lo à palavra, fazer sua fala se tornar a emissão. Essa reviravolta fazia eco à frase de Brecht, antes da Guerra, de que o mesmo aparelho (o rádio) que serve para receber informações, serve também para enviá-las.

No movimento social europeu tratava-se de construir um receptor crítico. Isso seria possível com a participação do ouvinte nas emissões da "rádio delirante", com um jornal que politizasse as subjetividades, com o teatro de rua (action painting) que rompesse com o caráter representacional da peça, através de processos que o estimulassem a produzir seus próprios produtos mediáticos.

A mobilização para a construção de uma esfera pública participante, que fizesse oposição ao monopólio comunicacional das redes de rádio, televisão e jornais, continuava ainda na busca do Potemkin, da criação de um sistema que fizesse frente à grande comunicação de massa, de caráter alienante e estupidificante. Mas os meios são os mesmos, se trata apenas de uma briga por posições. Por isso, também essas iniciativas logo desapareceram em vista de falta de financiamento, pouco fôlego para as idéias, pouca maturidade política ${ }^{10}$.

A comunicação produzida em massa tem uma lógica intrínseca. Se ela vende produtos comerciais, idéias consumistas, sexo, ou se o interesse é, ao contrário, "conscientizar", como se dizia na época, o mecanismo utilizado é em última análise o mesmo: uma idéia (ou vontade, ou interesse), um grande meio na mão e uma prática. $\mathrm{O}$ estimulo do consumismo ou do educacionismo têm, ambos, o mesmo viés: o exercício de uma forma (ou de uma vontade) de poder.

Talvez a era tecnológica, com seus processos de interatividade, virtualidade, anonimato esteja lançando outras variáveis na cena, variáveis essas que nos permitam rever - numa era sem a preponderância da ideologia" - a questão do saber-ouvir (ou do saberver) e do saber-narrar.

\section{4}

$\mathrm{O}$ que os agentes do processo de comunicação do passado não viam era que $o$ ato de receber mensagens envolve certos contratos específicos. A era da produção em massa de 
mensagens, aproveitando-se das possibilidades excepcionais da indústria da cultura, considerava o receptor uma espécie de "matéria prima" a ser trabalhada por essa indústria. Ignorava que no território da recepção ocorriam reações, adesões ou rejeições, o ouvir atento e o receber disperso, diálogos e silêncios, emoções e tédios, momentos de alto envolvimento, de vibração, de “desopilação", de curiosidade. Em suma, que no campo da audiência ocorria efetivamente um processo social que caberia investigar mais densamente.

É natural que a célula familiar tenha se transformado com a instalação do aparelho de televisão em seu centro. Os fragmentos que hoje possuímos de uma época sem televisão nos dizem muito pouco da vida pré-televisiva, menos ainda da vida pré-radiofônica. É sabido que a industrialização do século $19 \mathrm{deu}$ formação aos centros urbanos (entre 1860 e 1900 as cidades industriais aumentaram cinco vezes seu volume), mas há poucas indicações do lazer dessa época. Aparentemente as populações aumentadas de algumas importantes cidades industriais da época buscavam seu lazer nas tabernas, nos cabarés, nos teatros populares, nos $\operatorname{circos}^{12}$.

Foram formas que se expandiram com o aumento da população e da demanda cultural desses centros industriais emergentes, mas pouco se sabe da relação do receptor com essas iniciativas: a cultura era oferecida como uma mercadoria qualquer e não se pesquisava nem o feedback do receptor nem a relação que este mantinha com os demais que constituíam seu circulo. Além do mais, estas eram promoções outdoor, isto é, associadas com uma vida pública e um universo de entretenimento de boulevards, sem qualquer indicação do ambiente domiciliar particular.

Este parecia ainda guardar o clima da vida rural em que as relações familiares se constituíam de diálogos elementares, da leitura de jornais ou livros, da realização de pequenos trabalhos domésticos. Somente com o advento do rádio, que nos primeiros anos entretanto não dispunha de altofalantes coletivos, pode-se dizer que se inicia a interferência direta da comunicação de massa nos domicílios, tornando-se um sistema de ruptura do cocoon familiar e pondo em xeque a autonomia da família na definição do que entra e do que se discute no interior do domicílio.

Do rádio para a televisão a transformação da recepção foi em graus de intensidade e qualidade. Se a recepção auditiva decai em função das imagens, a penetração das mensagens externas torna-se, contrariamente, menor. Ou seja, a dependência das pessoas às emissões da comunicação era muito mais forte no período do rádio do que no período da televisão. A audição tem uma força de impregnação mais forte do que a televisão exatamente porque, ao se ouvir, o mundo penetra em nosso interior, ao passo que quando vemos somos nós que nos projetamos nele. ${ }^{13}$

Marshall McLuhan dizia que a televisão era um meio frio, em oposição a outros — como o rádio - que são meios quentes. Em Understanding Media, ele aponta que os meios quentes ampliam apenas um sentido e de forma detalhada; em compensação, os meios frios apresentam tanto quantitativa quanto qualitativamente menos informação pois, por um lado, oferecem menos dados, por outro, estes são mais inespecíficos do que precisos ${ }^{14}$. O rádio, o livro e o filme são meios quentes; a pobreza de detalhes dos meios frios solicita ampliação e complementação da comunicação por parte dos receptores, esses meios exigem, dizem Kloock e Spahr, a “ participação pessoal do público". ${ }^{15}$

Dessa forma, o rádio, na origem dos processos de comunicação que interferem no ambiente domiliciar do receptor, era mais formativo, atuava de forma educativa mais intensivamente,
12) "Durante a década seguinte ao advento da projeção de filmes, estes eram mostrados como partes de programas de vaudeville ou de variedades, em camavais ou em parques de feiras, salas de leitura e igrejas" cf. Microsoft Encarta Encyclopedy 1999.

13 ) Freud fala de representação da palavra em oposição à representação da coisa. Enquanto a primeira é essencialmente acústica, a segunda é visual. As representações de palavra são introduzidas numa concepção que liga a verbalização e a tomada de consciência, ao passo que o sistema inconsciente apenas compreende a representação da coisa. (Cf. J. Laplanche e J. B. Pontalis, Vocabulário da psicanálise. 7a ed., São Paulo, Martins Fontes, p.584-585). Há portanto um privilégio na representação da palavra. Aqui cabe também a frase utilizada por Joachim-Emst Berendt: "O olho conduz o homem ao mundo; o ouvido leva o mundo ao homem".

Segundo ele, o primado do olho começou na história ocidental com o racionalismo e é diametralmente diferente das antigas culturas dássicas, que afirmavam que "o ouvido é o caminho "(como no Upanixade). Cf. sua obra Ouvir o Mundo. (Vom Hören der Welt. Das Ohr ist der Weg. Frankfurt/M. Network Medien-Cooperative, s/d.) 14) Cf. Daniela Kloock e Angela Spahr. Medientheorien. Eine Einführung. Munique, W. Fink, 1997, p. 53-54. 15)Idem, p. 54. 
16) Eco, U. Viagem na irrealidade cotidiana. Rio de Janeiro, Nova Fronteira, p. 191.

17) Lucien Sfez acredita - citando Thayer - que o receptor é criador da mensagem por adesão a um contrato de comunicação. Ele "atribui" significação: o sentido é inventado no ato. Sfez, L Crítica da Comunicação, S.Paulo, Loyola, 1994, p. 90.

18) Os estudos empíicos norteamericanos descobriram, por meio da teoria dos dois níveis da comunicação [1954, Elihu Katze Paul Lazarsfeld e sua teoria dos "líderes de opinião"], que todo processo de emissão em massa de mensagens por meio de algum grande veículo (jornal, rádio, televisão) depara-se com receptores diferenciados: uns recebem a informação na qualidade de "conhecedores do assunto", retraduzindo-as aos outros, menos informados, que são como que influenciados por estes na maneira de recebê-las e mesmo de as absorverem.

19) Baldelli, P. Informazione e controinformazione. Milão, 1972, p. 10. construía de maneira mais densa a posição e a ilustração dos receptores; diferentemente, a televisão, apesar de ter suplantado o rádio em termos de amplitude, extensão e importância, o faz de forma mais epidérmica, suas mensagens são tomadas de maneira difusa e não específica, é um meio menos formador. A televisão, conforme McLuhan, exige do receptor uma participação, não por ser um meio mais democrático, interfacial, dialogai, mas por ser mais superficial. Enquanto o rádio dialoga internamente com $\mathrm{o}$ receptor, introduz informações e conceitos que o fazem - se bem que em geral individualmente - pensar em seu mundo, a televisão mostra planos externos e informações "do lado de lá", dificultando uma relação ou mesmo um envolvimento efetivo.

Por isso, a discussão atuai da recepção deve considerar que a "era da TV" foi um período rico em imagens mas pobre em conceitos, em formação, em efetiva introdução de novidades no receptor. E que a relação de recepção criada não motivou efetiva troca mas um relacionamento antes descrente, cínico, desinteressado.

Umberto Eco disse, em seu célebre artigo sobre a $\mathrm{TV}$, que seu público não se interessa se o que a TV fala é verdade ou mentira; importa, isso sim, que sua emoção seja verdadeira ${ }^{16}$. Vê-se por ai que a relação do receptor com o meio não é o de credibilidade mas o de espetáculo, de fascínio, de desprendimento. Por esse motivo, igualmente, seu contrato de comunicação não é de contestação, mas de uma relação mais lúdica com o meio ${ }^{17}$.

Convém então agora avaliar como se dá a relação dos receptores atuais da comunicação, envoltos que estão com uma televisão de múltiplos canais, com o telecomando, com a dita "interatividade", em suma, num quadro em que não recebem apenas informações que os fazem refletir ou que os dispersam num universo de cores, imagens espetaculares e impactos, mas que "interferem" na co-produção dos conteúdos. Em uma palavra, mudou a recepção, mudou o processo de comunicação, mudaram as imposições ou as trocas- comunicacionais, ou estaríamos apenas num outro nível de relação desigual? Estaria voltando o saber-ouvir e o saber-narrar? Estaria de volta o sujeito recontextualizante ou isso seria uma ilusão nostálgica e o sistema continua - e agora talvez com mais força - a anular os invidíduos?

$$
5
$$

Os anos 60 introduziram pela primeira vez criticamente a questão da audiência ${ }^{18}$. Tratava-se, naquela época, de vitalizar a recepção, de tornar o cidadão não apenas um receptor, mas um "sujeito" da recepção. Isso significava algo como "aprender a decodificar", desmontar as notícias, por exemplo, e dar-lhes uma interpretação nova. Umberto Eco e Pio Baldelli teorizavam-na como interpretação e julgamento crítico das notícias. Para Baldelli, a contra-informação partia da informação normal e dela extraía seu conteúdo próprio ${ }^{19}$. Eram iniciativas para desmascarar, desvendar complôs, estimular a discussão pública sobre temas que era silenciados pelos grandes meios de comunicação.

A época, entretanto, era marcada por uma ostensiva dualidade entre a informação socialmente necessária e importante e as manobras manipulativas de redes monopolistas de comunicação, ou seja, havia efetivamente uma batalha ideológica no interior do processo comunicacional. Eram anos de agonistica politica, de verdadeiro combate pela conquista da opinião pública para argumentos situacionistas ou oposicionistas. Ou seja, tempos de ideologia, da polarização esquerdadireita, da conquista de "cabeças", arregimentação em torno de bandeiras.

Esse tempo passou. $\mathrm{O}$ próprio Umberto Eco reconhece em seu texto sobre a televisão que esse tempo já não 
existe ${ }^{20}$, que o período dito "pósmoderno" inaugura uma sociedade em que há um embaralhamento total das ideologias, das intenções, dos projetos. Que não há um inimigo no outro fronte, que seja facilmente identificável e atacável. A era do totalitarismo branco da opção única (uma política: a neoliberal, uma economia: globalizada, uma comunicação: internetizada), veio com a falência da era dos embates ideológicos e seus três componentes determinantes: o desencanto, a crise dos meta-relatos e a pós-história. ${ }^{21}$

Por isso, a questão da recepção e da realização ou desrealização do sujeito mudam totalmente de caráter. Já há uma participação mas é participação, sem resultados, sem efeitos, sem efetiva intervenção. Participa-se na escolha entre os infinitos canais, participa-se da construção de programas e filmes como mosaicos, pastiche de diferentes programas constituindo um produto híbrido, desconexo, curioso, mas jamais crítico ou contundente. Participa-se no jornalismo intervindo na matéria escrita, dando seus comentários, julgando a qualidade do texto, sua pertinência, definindo-se aí, por critérios sem muita relevância, se o profissional permanece ou não no quadro da empresa. Trata-se de uma participação perversa, pois já não se trata de interferir para a produção de um melhor, mas para aumentar o entretenimento, a ligeireza, a legibilidade, em suma, sob critérios de consumo e não mais de qualidade informativa.

Há um componente perigoso nos processos interativos massa-mediáticos de comunicação e de participação: um gosto de padrão médio, pouco exigente, pouco disposto a leituras densas, com pressa e pouca paciência impõe-se como o critério de excelência. Com isso, a cultura é forçada a manter-se no plano do trivial e do conhecido; as ousadias editoriais - assim como as do cinema, da literatura, do teatro, por exemplo - caem no campo do "não há demanda", do "ninguém quer isso", do fora de moda.
O público não é mais passivo, se é que algum dia de fato o foi. Hoje ele participa, envia fax, e-mails, faz telefonemas, insiste em dar sua opinião. Só que na atual configuração da comunicação, participar tomou-se não apenas lugar comum (portanto, sem valor), mas o próprio eixo do sistema, em uma palavra, foi incorporado, neutralizou-se, domesticou-se inteiramente. O estranho é não participar. Num processo em que há uma inundação de opiniões, intervenções, obsessões por falar, se exprimir, dar sua opinião, aparecer, em suma, isso já não tem mais qualquer efeito. Por força da hipertelia, a estimulação do receptor em participar acabou dando em seu contrário: a inutilidade de qualquer participação, seu desaguamento numa vala comum do excesso, do despercebido, do absolutamente inofensivo, inodoro, inútil.

E num mundo em que todo mundo quer falar, o raro passa a ser alguém que se interesse por ouvir. A inflação de vozes - como de jornais, boletins, de web sites em toda parte, cada um querendo provar que existe-, o ensurdecedor aparelho de multiplicação de todas as comunicações - desde as mensagens de felicidades e parabéns, que são do domínio da esfera privada mas que para ganhar legitimidade precisam se expor publicamente como se fossem campanhas de vacinação -, os sistemas que hoje se propõem a satisfazer a todos em seus delírios por serem ouvidos constituem um mundo barulhento, poluído sonora, visual, sensitivamente, que ninguém de fato suporta.

Um mundo do bombardeamento maciço de informação dos grandes monopólios de comunicação foi substituído por outro, o da indústria da democratização, que vende a todos a ilusão de aparecer, de ser alguém, de marcar - não importa de que forma sua existência, cada vez mais reduzida nos tempos atuais a uma insignificância brutal e trágica.
20) "Era uma vez os mass media, que eram maus, é sabido, e havia

um culpado. Depois havia vozes virtuosas que acusavam seus crimes./.../Pois bem, tudo acabou. Temos que começar de novo a nos perguntar o que está acontecendo"

(1983). Eco, U., op. cit., p. 181. 21) Pelo processo universal de desencanto, a técnica moderna põe abaixo todas as aspirações da modemidade, incorporadas peto Projeto Iluminista, assim como as ilusões do humanismo, de privilégio do homem, de evolução e progresso da espécie, de melhoria crescente das sociedades em direção ao reino da felicidade. Com a crise dos meta-relatos efetiva-se a crise das ideologias comunista, socialista, liberal ou fascista e sua extinção do campo das fantasias sociais possíveis . Não havendo mais bandeiras por que lutar, não existindo mais « destino feliz da humanidade », não havendo mais diferenças nítidas entres as culturas e os países, todos eles sob o manto conciliador (não raro totalitário) do neoliberalismo, a civilização planetária toma-se uma totalidade sem amanhã. O que marcava o engajamento, a força de Iuta, a combatividade dos homens da modemidade era uma «agonística geral» : a politica, as investidas econômicas, 0 desenvolvimento da ciência, o campo de batalha cultural, mesmo a arte, a poesia, a música, a literatura, a subjetividade, em suma, tudo se situava num terreno de expectativas, avanços e recuos, vitórias e derrotas. Toda a vivência social era marcada pela agonística: como num jogo, numa luta, numa história de conquista, cada empreendimento individual, grupai, coletivo, mesmo nacional era uma maneira de se posicionar nesse «jogo », onde o que 
interessava era a vitória final. $A$

canalização de energias, 0

sentimento solidário entre os

correligionários, a condição

psicológica de « fazer parte de uma

força », preenchiam a vivência em

sociedade com enorme vitalidade,

espíito de luta, empenho. Por fim, a

pós-história instala, ao contrário disso,

o dima de eliminação do jogo, de

todos os jogos, a impossibilidade do

«lutar contra ». Só existe um

arrastar-se para frente, um empurrar

com a barriga, uma ação sem

convicção nem vontade, um

« desejo do nada ». Com a religião e

seu ascetismo, dizia Nietzsche, 0

sofrimento, a dor tinham algum

sentido: sofria-se por causa da

« culpa ». O novo ideal ascético do

homem (niilista) tecnológico é talvez

pior, pois não tem explicação,

sentido: deseja-se o nada porque,

excetuando-se os equipamentos

eletrônicos, todo o resto acabou.

22) Sfez, L, op. cit., p. 95ss.

23) "...vem ocorrendo não apenas a

crise dos conceitos caros ao

pensamento moderno, tais como

"razão", "sujeito", "totalidade",

"verdade", "progresso". Constatamos

que ao lado dessa crise opera-se

sobretudo a busca de novos

enquadramentos teóricos...

legitimadores da produção científico-

tecnológica numa era que se quer

pós-industrial. /.../ Assim sendo, a

atividade científica deixa de ser

aquela práxis que, segundo a

avaliação humanístico-liberal,

especulativa investia na formação do

"espirito", do "sujeito razoável", da "

pessoa humana" e até mesmo da

"humanidade". Com ela, o que vem

se impondo é uma concepção da

ciência como tecnologia intelectual, ou seja, como valor de troca e, por

isso mesmo, desvinculada do

produtor (cientista) e do

consumidor."Barbosa, Wilmar do V., "Prefácio", em Lyotard, J.F., op.cit., pp. viil ex.

24) Carroll, L. Alice no país do espelho.
Naturalmente o saber-ouvir e o saber-narrar distanciam-se desse universo em que, ao contrário, a inflação de falas e vozes impede que se ouça qualquer coisa e que se recupere a capacidade de aprender pela absorção das mensagens comunicacionais. Ouvir hoje tornou-se de fato ler, romper o desafio de ir em busca de textos, do silêncio das participações que nos forçam a ouvi-las, a lê-las. O saber-ouvir tornou-se muito mais, por isso, um saber-ler, um processo de conseguir atravessar - sem se molhar, sem se perder em tanta espuma - esse oceano imenso de angústias por comunicação. A recuperação da leitura, disto que vamos buscar e não daquilo que quer por toda a lei se impor a nós. Só através disso o saber-narrar pode emergir como um procedimento crítico, autônomo, livre.

A comunicação não apenas vicia; ela atrela as pessoas na fantasia vã de lhes garantir a prova de existência. É sua grande ideologia, novo sistema de escravidão que torna todos presos ao mesmo destino. Michel de Certeau dizia que os sujeitos deveriam manter um distanciamento em relação aos media de massas.

Lucien Sfez equivoca-se ao dizer que as teorias de recepção oscilam em ter duas posições opostas, uma, advogando que o receptor é diverso, tem filtros, recontextualiza, é criativo; o emissor aqui estaria enfraquecido e sua capacidade de influenciar estaria anulada mediante a participação do receptor. Trata-se da corrente anglosaxônica da comunicação. A outra corrente, chamada de européia, advoga que o sistema anula a diferença individual, o sujeito de desrealiza, o circuito é todo-poderoso e nele o indivíduo não pode em nada interferir. ${ }^{22}$

São as posições apontadas no início como racional-cartesiana e críticaestruturalista. Parece que hoje em dia nenhuma delas detém o privilégio da razão, pois nem existe mais o sujeito "recontextualizante", herança do sujeito kantiano da emancipação ${ }^{23}$, nem o todo opera de forma assim abrangente. Criouse um contexto novo, fora dos padrões conhecidos de sobreposição do todo (da totalidade expressiva, do "sistema", da estrutura sobre os sujeitos) ou, menos ainda, de capacidade de interferir dos cidadãos. A mudança deveu-se às transformações sociais, culturais e políticas advindas da chamada "era tecnológica”. Esta era rompeu com a ordem dominante na organização social capitalista anterior e instituiu um novo processo, agora regulado por uma ordenação sistêmica que se rege por outros condicionantes.

A era tecnológica opera antes com pares paradoxais: democracia como opressão, excesso como satisfação, liberdade como angústia, ausência de destino como destino, inexistência como vida, e assim por diante. É uma outra ordem lógica, imperceptível para os que se mantêm nas lógicas formais e clássicas, que hoje já não nos dizem nada, pois o real é paradoxal.

Nesse conjunto, perguntar-se sobre a recepção dos meios de comunicação é como imaginar tartarugas com cabeça de bezerro, elefantes fabricando mel, uma mosca do tamanho de um frango ou um sorriso de um gato, sem o gato. ${ }^{24}$ A questão recepção desapareceu com a "paleo-TV" de Eco, com paleomundo das contendas ideológicas, pois aquele quadro, aquela época separava instâncias, domínios, oposições. Hoje, ao contrário, tudo se funde sob a aparência das diferenças e das autonomias; hoje se coloca muito mais a questão do envolvimento, da capturação dos homens dentro dos sistemas informáticos e de sua transformação em agentes de sua própria produção. $\mathrm{O}$ novo sistema não manipula, não falsifica nada, não se usa de expedientes humanos de sedução; é a própria tecnologia como um todo que realiza o trabalho, contando com os homens como seus agentes voluntários e determinados. A crítica ideológica 
mudou de nível: é preciso que saibamos agora onde encontrá-la.

A recepção era parte de uma visão setorizada e parcializada da produção da comunicação. No momento em que a comunicação se tornou nossa vida, nossa existência material e nossa dimensão metafísica ${ }^{25}$, não há como proceder a discursos parciais. A tecnologia radicaliza as questões e não permite alternativas; nesse caso, o destino do pensamento e do atrevimento humano só podem se situar no plano do questionamento de todos os territórios onde a tecnologia impregnou com seu evangelho de libertação, salvação, purificação.

\section{Bibliografia do autor}

- Massenmedien als politische Handlung. H. P. Gerhardt, Frankfurt, 1981.

- O discurso sufocado. Ed. Loyola, São Paulo, 1982.

- A televisão. Ed. scipione, São Paulo, 1985.

- Ideologia. Ed. Global, São Paulo, 1985.

- O capital da notícia. Ed. Ática, São Paulo, 1986.

- Quem manipula quem? Ed. Vozes, Petrópolis, 1986.

- Violência das massas no Brasil. Ed. Global, São Paulo, 1986.

- Violência política. Ed. Moderna, São Paulo, 1986.

- Televisão, a vida pelo vídeo. Ed. Moderna, São Paulo, 1988.

- Jornalismo fin-de-siècle. Scritta, São Paulo, 1993.

- Sociedade tecnológica. Ed. Scipione, São Paulo, 1994.

- Superciber. A civilização místico-tecnológica do século 21. Ed. Ática Shopping Cultural, São Paulo, 1997.

- A saga dos cães perdidos. Ed. Hacker, São Paulo, 2000.

\section{Coletâneas}

- Imprensa e capitalismo. Ed. Kairós, São Paulo, 1984.

- A linguagem da sedução. Com-Arte, São Paulo, 1985; Perspectiva, São Paulo, 1988.

- Política e Imaginário nos meios de comunicação. Ed. Summus, São Paulo, 1985.

\section{Coletivo NTC}

- Pensar-Pulsar. Cultura comunicacional, tecnologias, velocidade. Edições NTC, São Paulo, 1996.

- Vivências eletrônicas: sonhadores e excluídos. Edições NTC, São Paulo, 1998. 